\title{
Pengendalian Kebisingan pada Fasilitas Pendidikan Studi Kasus Gedung Sekolah Pascasarjana UGM Yogyakarta
}

\author{
Jarwa Prasetya S. Handoko \\ Jurusan Arsitektur Fakultas Teknik Sipil dan Perencanaan \\ Universitas Islam Indonesia \\ email: jarwa.prasetya@staff.uii.ac.id
}

\begin{abstract}
Abstrak
Kebisingan merupakan masalah yang menyertai perkembangan pembangunan kota, sebagai akibat meningkatnya jumlah penduduk dan aktivitas penduduk di perkotaan. Kebisingan yang kita dirasakan, dapat kita kurangi tingkat gangguannya dengan melakukan upaya pengurangan atau pengendalian kebisingan. Seiring dengan berkembangnya pembangunan disegala bidang di Indonesia dan di Yogyakarta pada khususnya, meningkatnya pertumbuhan sarana dan prasarana transportasi darat menyebabkan kebisingan dari arus lalu lintas yang ada menjadi tidak terhindarkan.

Gedung Sekolah Pascasarjana UGM sebagai salah satu bangunan milik UGM yang berfungsi untuk kegiatan pendidikan, berlokasi di Bulaksumur utara yang merupakan kawasan yang sangat pesat perkembangannya, baik pertumbuhan permukiman penduduk maupun arus lalu lintasnya, sehingga memiliki tingkat kebisingan lingkungan yang cukup tinggi.

Sebagai gedung untuk pendidikan perguruan tinggi, Gedung Sekolah Pascasarjana UGM diharapkan dapat menjadi tempat yang kondusif bagi terlaksananya kegiatan akademik, sehingga dibutuhkan tingkat kebisingan yang rendah. Hal tersebut membutuhkan suatu pengendalian kebisingan lingkungan di Gedung Sekolah Pascasarjana UGM. Pengendalian kebisingan dilakukan terhadap kebisingan ekterior dan interior seluruh bangunan.

Dengan makalah ini dapat diperoleh gambaran umum tentang upaya yang dilakukan, manfaat yang diperoleh dan kekurangan- kekurangan yang terdapat dalam pengendalian kebisingan pada fasilitas pendidikan dengan studi kasus Gedung Sekolah Pasca Sarjana UGM Yogyakarta. Makalah ini merupakan suatu proses evaluasi purna huni level indikatif dengan metode deskriptif mengenai pengendalian kebisingan yang dilakukan dikaitkan dengan indikasi keberhasilan pengendalian kebisingan pada bangunan.

Terdapat beberapa rekomendasi dari pembahasan yang dilakukan pada makalah ini yaitu: (1) pemilihan site atau lokasi fasilitas pendidikan dioptimalkan pada daerah dengan kepadatan penduduk rendah dan diusahakan tidak pada pusat ekonomi, (2) pengendalian kebisingan interior, efektif dilakukan dengan perancangan organisasi ruang yang mempertimbangkan fungsi dan tingkat kebisingan yang diijinkan untuk fungsi bersangkutan, (3) pengendalian eksterior dapat dilakukan dengan menggunakan penghalang dan atau barier bising, memperluas sempadan bangunan, meletakan bangunan yang membutuhkan ketenangan pada posisi terjauh dari sumber kebisingan lingkungan yang ada. Selain itu dapat menggunakan parfum akustik yang berupa gemericik air untuk menyamarkan kebisingan lingkungan yang terjadi.
\end{abstract}

Kata kunci: kebisingan, pengendalian kebisingan, fasilitas pendidikan

\section{Pendahuluan: Pentingnya Pengendalian Kebisingan}

Sasaran pengendalian kebisingan adalah menyediakan lingkungan akustik yang dapat diterima di dalam maupun di luar bangunan, sehingga intensitas dan sifat semua bunyi di dalam atau sekitar suatu bangunan tertentu akan cocok dengan keinginan penggunaan ruang tersebut. Bebas bising merupakan salah satu dari kualitas lingkungan yang paling berharga yang dapat dimiliki suatu gedung atau ruang eksterior dewasa ini. 
Pengendalian kebisingan yang efektif dalam bangunan sangat diperlukan karena kebisingan dapat menyebabkan kerusakan telinga sementara ataupun permanen, mengganggu dalam mendengarkan pembicaraan atau musik, menyebabkan kemunduran dalam penampilan kerja, menurunkan konsentrasi belajar, mengalihkan perhatian atau mengganggu.

Permasalahan utama dalam pengendalian kebisingan adalah meramalkan bagaimana bising yang diduga akan mempengaruhi penghuni ruang yang ada, menetapkan jejak penyebaran bising dan menghindari setiap pengaruh yang merusak. Seiring dengan berkembangnya pembangunan di Yogyakarta, meningkatnya pertumbuhan sarana dan prasarana transportasi darat menyebabkan kebisingan dari arus lalu lintas yang ada menjadi tidak terhindarkan.

Gedung Sekolah Pascasarjana UGM sebagai bangunan yang berfungsi untuk kegiatan pendidikan, berlokasi di Bulaksumur utara yang merupakan kawasan yang sangat pesat perkembangannya, baik pertumbuhan permukiman penduduk maupun arus lalu lintasnya, sehingga memiliki tingkat kebisingan lingkungan yang cukup tinggi.

Sebagai gedung untuk pendidikan perguruan tinggi, Gedung Sekolah Pascasarjana UGM diharapkan dapat menjadi tempat yang kondusif bagi terlaksananya kegiatan akademik, sehingga dibutuhkan tingkat kebisingan yang rendah. Hal tersebut membutuhkan suatu pengendalian kebisingan lingkungan di Gedung Sekolah Pascasarjana UGM. Pengendalian kebisingan dilakukan terhadap kebisingan ekterior dan interior seluruh bangunan.

\section{Kajian Pustaka}

\section{Kebisingan Lingkungan}

Kebisingan atau bising dapat didefinisikan sebagai bunyi yang mengalihkan perhatian, mengganggu, atau berbahaya bagi kegiatan sehari-hari (kerja, istirahat, hiburan atau belajar) dan merupakan bunyi yang tidak diinginkan oleh penerima. Sehingga hal ini mengandung unsur subyektifitas, apakah bunyi secara psikologis diinginkan atau tidak oleh seseorang tersebut.

Ada 3 faktor yang menyebabkan sebuah suara secara psikologis dianggap bising, yaitu volume $(d B)$, perkiraan dan pengendalian. Selama gelombang-gelombang suara itu tidak dirasakan mengganggu manusia, maka namanya bunyi (voice) atau suara (sound). Dan dinamakan bising atau berisik (noise) jika gelombang-gelombang suara tersebut dirasakan sebagai gangguan. Karena bising tidak dikehendaki, maka sifatnya adalah subyektif dan psikologik. Subyektif karena sangat bergantung pada orang yang bersangkutan (Bell et. al., 2001). Misalnya suara musik rock bagi seorang remaja adalah bunyi yang menyenangkan, namun untuk ibunya merupakan bising yang 
mengganggu. Karena sifatnya yang mengganggu itu, secara psikologik, bising adalah penimbul stress (stressor).

Bising dapat diukur dengan bantuan meter tingkat bunyi (sound level meter) dalam satuan decibel $(d B)$. Menurut Doelle dan Lea (1986), kebisingan dapat dikelompokan berdasarkan sumber bising dapat menjadi:

a. Bising Interior

Bising Interior merupakan bising lingkungan yang terjadi di dalam gedung (bangunan) dan berasal dari suara manusia, alat rumah tangga, atau mesin-mesin gedung. Dinding pemisah, lantai, pintu dan jendela harus mengadakan perlindungan yang cukup terhadap bising-bising ini di dalam gedung. Sumber bising yang paling sering dibuat oleh manusia adalah bunyi radio, televisi, pembicaraan yang keras, bantingan pintu, langkah kaki di tangga. Bising yang disebabkan alat-alat rumah tangga seperti kipas angin, motor, kompresor, pencuci piring, penghancur sampah, pembersih vakum, pembuat kilap lantai, pengering rambut, pencukur listrik.

Tingkat bising di dalam suatu ruangan terdiri dari dua jenis:

- Bunyi yang secara langsung diterima dari sumber.

- Bunyi dengung (atau yang dipantulkan) yang mencapai posisi tertentu setelah pemantulan berulang-ulang.

Bising interior dapat dihasilkan dari bunyi yang timbul di udara dan bunyi yang timbul karena struktur bangunan atau getaran mesin. Bila bunyi ditransmisi lewat udara saja maka disebut bunyi di udara, misalnya suara percakapan manusia, bunyi alat-alat musik. Bila suatu sumber bunyi tidak hanya memancarkan energinya lewat udara tetapi juga serentak menyebabkan bagian-bagian kerangka bangunan yang padat bergetar maka disebut sebagai bunyi truktur atau bunyi benturan, misalnya bising langkah kaki manusia, bising oleh mesin- mesin.

b. Bising Eksterior

Bising eksterior merupakan bising lingkungan yang berasal dari lalu lintas, transportasi, industri, alat-alat mekanis yang tampak (exposed) dalam bangunan (menara pendingin, pengkondisi udara, kompresor). Yang paling mengganggu adalah bising yang dihasilkan oleh kendaraan, transportasi rel, transportasi air dan transportasi udara.

\section{Pengendalian Kebisingan pada Bangunan Fasilitas Pendidikan}

Pengendalian bunyi pada bangunan pendidikan mempertimbangkan: 
a. Pemilihan tempat dan perencanaan tempat (site)

Sebelum menentukan tempat atau lokasi bangunan akan didirikan harus dipertimbangkan bahwa gedung-gedung yang membutuhkan lingkungan bunyi yang tenang (sekolah, rumah sakit, lembaga penelitian) diletakkan pada tempat-tempat yang tenang, jauh dari jalan raya. Gedunggedung yang tidak mudah dapat menerima bising dapat digunakan sebagai penahan bising dan dapat diletakkan diantara sumber bising dan daerah yang membutuhkan ketenangan.

b. Perancangan akustik ruang dari ruang-ruang kelas, ruang kuliah, auditorium, ruang olahraga, ruang musik, ruang pandang dengar.

Rancangan arsitektur yang baik dengan memperhatikan kebutuhan akan pengendalian bunyi adalah pendekatan yang paling ekonomis dalam mengendalikan bising yang efektif dalam bangunan. Ruang yang diperkirakan akan menghasilkan bising harus diisolasi secara horisontal dan vertikal dari bagian gedung yang paling sukar mentolelir bising. Ruang yang membutuhkan ketenangan harus ditempatkan di bagian tenang dari site atau sisi bangunan. Sebagai contoh auditorium jangan ditempatkan berdampingan dengan ruang dengan peralatan mekanik.

Ruang-ruang yang tidak terlampau dapat menerima bising harus ditempatkan sedemikian rupa hingga berfungsi sebagai penghalang antara daerah yang bising dan daerah yang tenang, kepatuhan pada prinsip untuk memisahkan ruang yang bising dari ruang yang tenang pada tahap perencanaan akan mereduksi kebutuhan bahan bangunan atau sistem penginsulasi bunyi sampai suatu minimum, sehingga mengurangi biaya bangunan.

c. Pengendalian bising eksterior dan interior dalam seluruh bangunan.

Pengendalian atau pengurangan kebisingan dapat dilakukan terhadap salah satu diantara sumber kebisingan, media pengantar (berbentuk materi atau udara), dan manusia yang terkena dampak, atau pada ketiga hal tersebut.

- Pengurangan kebisingan pada sumbernya dapat dilakukan dengan memodifikasi mesin atau menempatkan peredam pada sumber getaran. Tetapi alternatif ini memerlukan penelitian intensif. Misalnya bising yang disebabkan oleh bantingan pintu dapat dihindari dengan menggunakan penahan pintu karet busa.

- Pengurangan kebisingan pada media transmisi menghabiskan biaya lebih murah dengan teknologi lebih sederhana asalkan perencanaannya matang. Bahan yang dapat menyerap suara, semisal busa atau ijuk dapat ditaruh diantara mesin dan manusia. Apabila sumber kebisingannya lalu lintas, penanggulangannya bisa dengan membuat jalur hijau dan penanaman pohon. Tanaman diyakini dapat mengurangi kebisingan, walau belum pernah 
ada penelitian berapa pengurangan kebisingan oleh satu pohon. Pengurangan kebisingan pada media transmisi dapat dilakukan dengan:

Dengan melindungi sumber bising dengan bukit atau penggundukan tanah (cutting) atau tanggul sepanjang tepi jalur dan harus ditempatkan sejauh mungkin dari daerah yang berpenghuni. Tanggul yang menghadap jalan raya harus semiring mungkin.

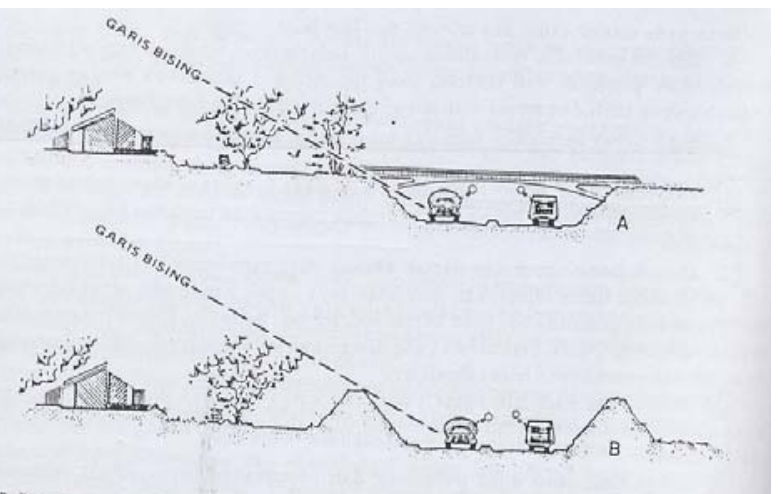

Gambar 1. Perlindungan kebisingan dengan gundukan tanah.

Bangunan yang sangat rentan (susceptible) terhadap gangguan bising dapat digunakan sebagai tameng (baffle) antara jalan yang bising dan daerah yang membutuhkan ketenangan.

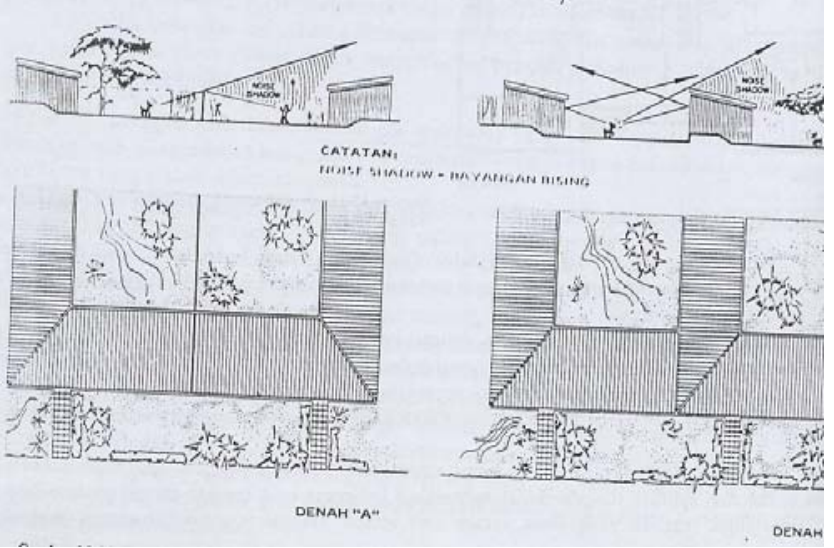

Gambar 2. Penghalang (baffle) antara jalan yang bising dan daerah yang membutuhkan ketenangan.

- Pemberian penghalang atau rintangan (pagar) yang tak terputus, padat dan tak berlubang antara sumber bising dan penerima akan mereduksi bising tergantung pada sudut bayangan bising dan tiggi efektif panghalang diatas garis yang menghubungkan sumber bising dengan penerima. Reduksi bising akan bertambah dengan bertambahnya sudut bayang-bayang bising dan tinggi penghalang. Panghalang yang rendah sepanjang jalur lalu lintas hanya akan mengadakan rreduksi bising yang dapat diabaikan di daerah di belakang penghalang. Supaya penghalang efektif secara akustik, maka harus dekat dengan sumber bising. 
- Penggunaan unsur vegetasi sebagai penghalang bising lingkungan. Semak-semak dan deretan pohon-pohon pada dasarnya tidak mengurangi bising pada frekwensi rendah dan mereduksi frekuensi-frekuensi tinggi hanya sekitar 1 sampai $2 \mathrm{~dB}$.

- Pengurangan kebisingan pada manusia yaitu dengan memproteksi telinga. Ada tutup telinga, ada juga sumbat telinga. Tutup telinga bisa menurunkan kebisingan antara 25-40dB, kemampuan sumbat telinga lebih kecil, tergantung bahannya. sumbat karet dapat menurunkan kebisingan 18-25 dB, sumbat cotton woll yang hanya menurunkan $8 \mathrm{~dB}$.

Seperti telah dipaparkan diatas bahwa tingkat bising dalam ruang penerima disebabkan oleh bunyi langsung dan bunyi pantul atau bunyi dengung. Tingkat kebisingan bunyi dengung dalam ruangan (interior) dapat direduksi dengan usaha penyerapan bunyi.

Menggunakan sebanyak mungkin lapisan bahan penyerap bunyi dalam ruang memiliki keuntungan sebagai berikut:

a. Ruang menjadi lebih tenang (kecuali untuk penerima yang menerima bunyi langsung).

b. Tingkat bunyi keseluruhan akan dikurangi. Energi bunyi yang lebih sedikit akan jatuh pada tembok ruang, sehingga transmisi bising dapat direduksi.

c. Lapisan penyerap bunyi cenderung melokalisir bising di daerah asalnya. Terutama untuk ruangruang mesin.

Pemakaian penyerap bunyi yang banyak dalam ruang terutama sepanjang lantai dan langit-langit ruang sirkulasi, seperti ruang depan, lobi, serambi. Penggunaan partisi pereduksi bising juga cukup efektif mereduksi bising ruangan (Doelle dan Lea, 1986).

Bahan penyerap bunyi yang digunakan untuk tujuan reduksi bising harus dipasang sedekat mungkin dengan sumber bising. Dan apabila permukaan ruang yang ada tidak mempunyai luasan yang cukup bagi bahan penyerap bunyi, maka penyerap ruang (space absorber) dapat digunakan. Bahan-bahan penyerap bunyi yang digunakan dalam rancangan akustik ruangan dapat diklasifikasi menjadi bahan berpori, penyerap panel atau penyerap selaput dan resonator rongga. Bahan berpori komersial dibagi menjadi 3 katagori: unit akustik siap pakai, plesteran akustik dan bahan yang disemprotkan, selimut akustik. Selain itu terdapat bahan akustik berpori yang penggunaannya serbaguna yakni karpet. Biasanya dipasang di lantai atau dinding, dapat menyerap bunyi dan bising di udara yang ada dalam ruang. Karpet meniadakan bising permukaan (langkah kaki, perpindahan perabot rumah). Dalam banyak situasi, masalah-masalah pengendalian bising dapat dipecahkan dengan menenggelamkan atau menyelimuti bising yang tak diinginkan lewat bising latar belakang. Bising buatan ini sering disebut minyak wangi akustik. 


\section{Metodologi}

Pembahasan pada makalah ini merupakan sebuah evaluasi purna huni. Evaluasi purna huni adalah salah satu bentuk penelitian yang memusatkan pada proyek yang telah ditempati (Snyder, 1991). Menurut Preiser ditulis bahwa evaluasi purna huni adalah penelitian yang bertujuan untuk mencari prestasi dan atau ketidaksesuaian, kesalahan serta kelalaian yang terjadi.

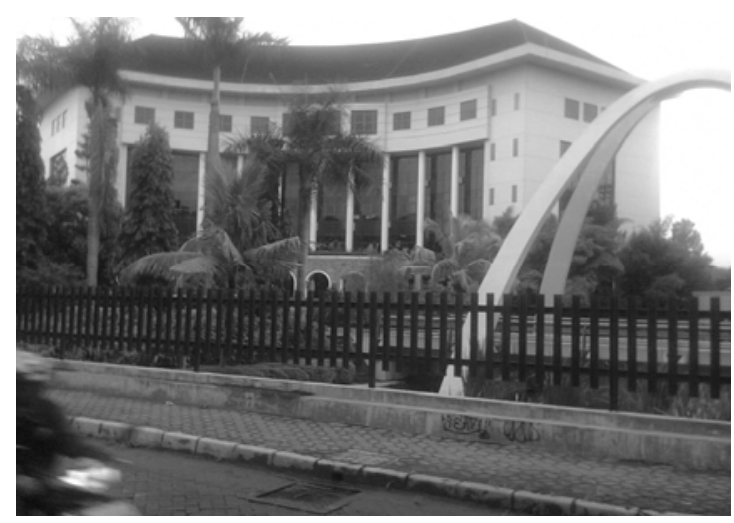

Gambar 3. Gedung Pasca Sarjana UGM Yogyakarta.

a. Apabila dilihat dari aspek pengamatan yang dilakukan dalam pembahasan makalah ini, evaluasi yang dilakukan merupakan evaluasi purna huni aspek teknis. Evaluasi purna huni aspek teknis ini bertujuan untuk mengevaluasi apakah bangunan sudah dapat memenuhi tujuan dilihat dari kriteria operasional penanganan dan pemanfaatan serta keselamatan. aspek kebisingan juga terkait dengan kriteria kesehatan bagi pengguna bangunan.

b. Apabila ditinjau dari target kedalaman evaluasi purna huni yang dilakukan maka pembahasan pada makalah ini termasuk dalam level evaluasi purna huni level indikatif. EPH Indikatif memiliki tujuan untuk menemukan indikasi kegagalan-kegagalan dan atau keberhasilankeberhasilan bangunan. Target dari analisis data dan pengorganisasian informasi pada tahap mendiskripsikan bangunan. Mendeskripsikan bangunan dengan metode commonsense untuk selanjutnya dilanjutkan dengan penelitian yang lebih mendalam. Dengan metode deskriptif mengenai pengendalian kebisingan yang dilakukan, dikaitkan dengan indikasi keberhasilan pengendalian kebisingan pada bangunan.

\section{Pengendalian Kebisingan pada Bangunan Sekolah Pascasarjana UGM Yogyakarta}

Gedung pusat sekolah pascasarjana UGM berlokasi di Pogung Yogyakarta, utara kawasan Bulaksumur. Merupakan salah satu fasilitas pendidikan yang dimiliki oleh Universitas Gadjah Mada (UGM) Yogyakarta. Mewadahi kegiatan akademik program magister dan doktoral di lingkungan UGM. 


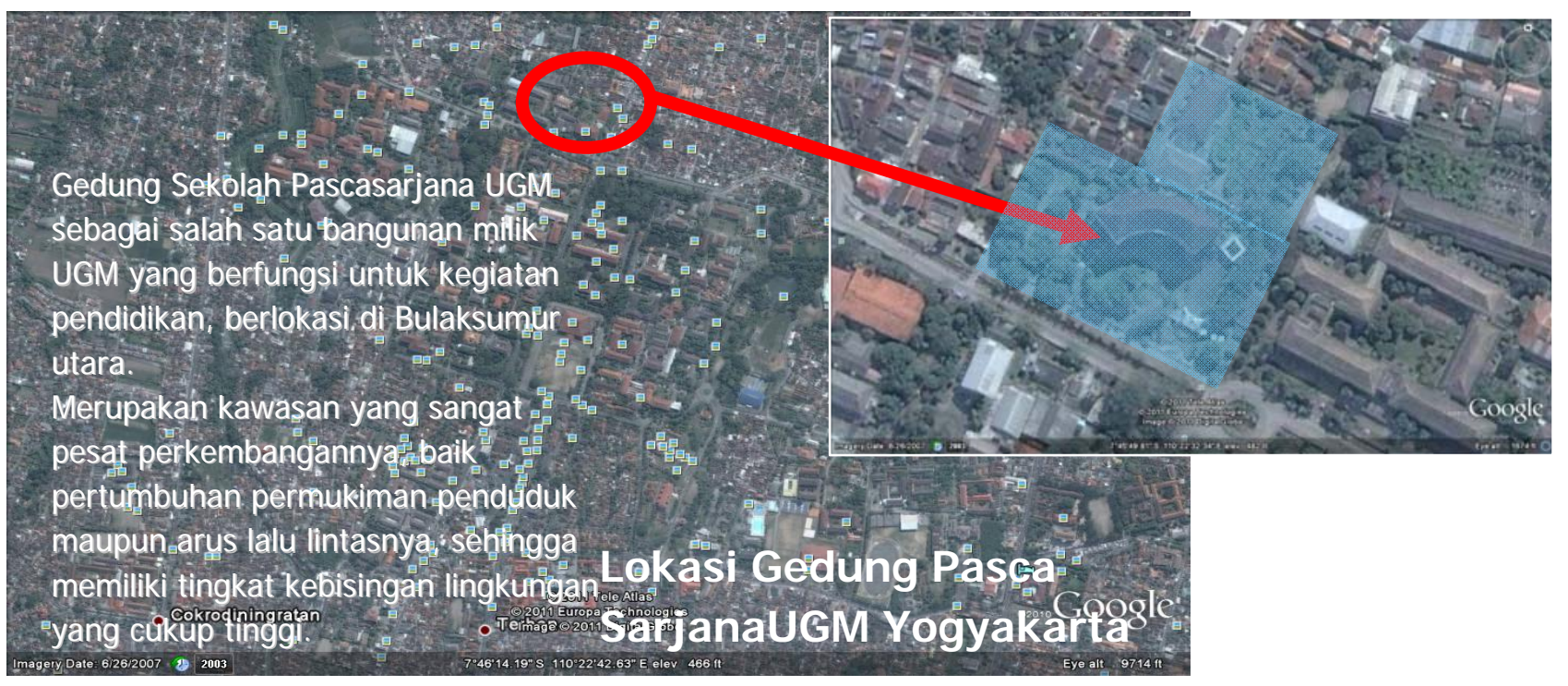

Gambar 4. Lokasi Gedung Pasca Sarjana UGM Yogyakarta.

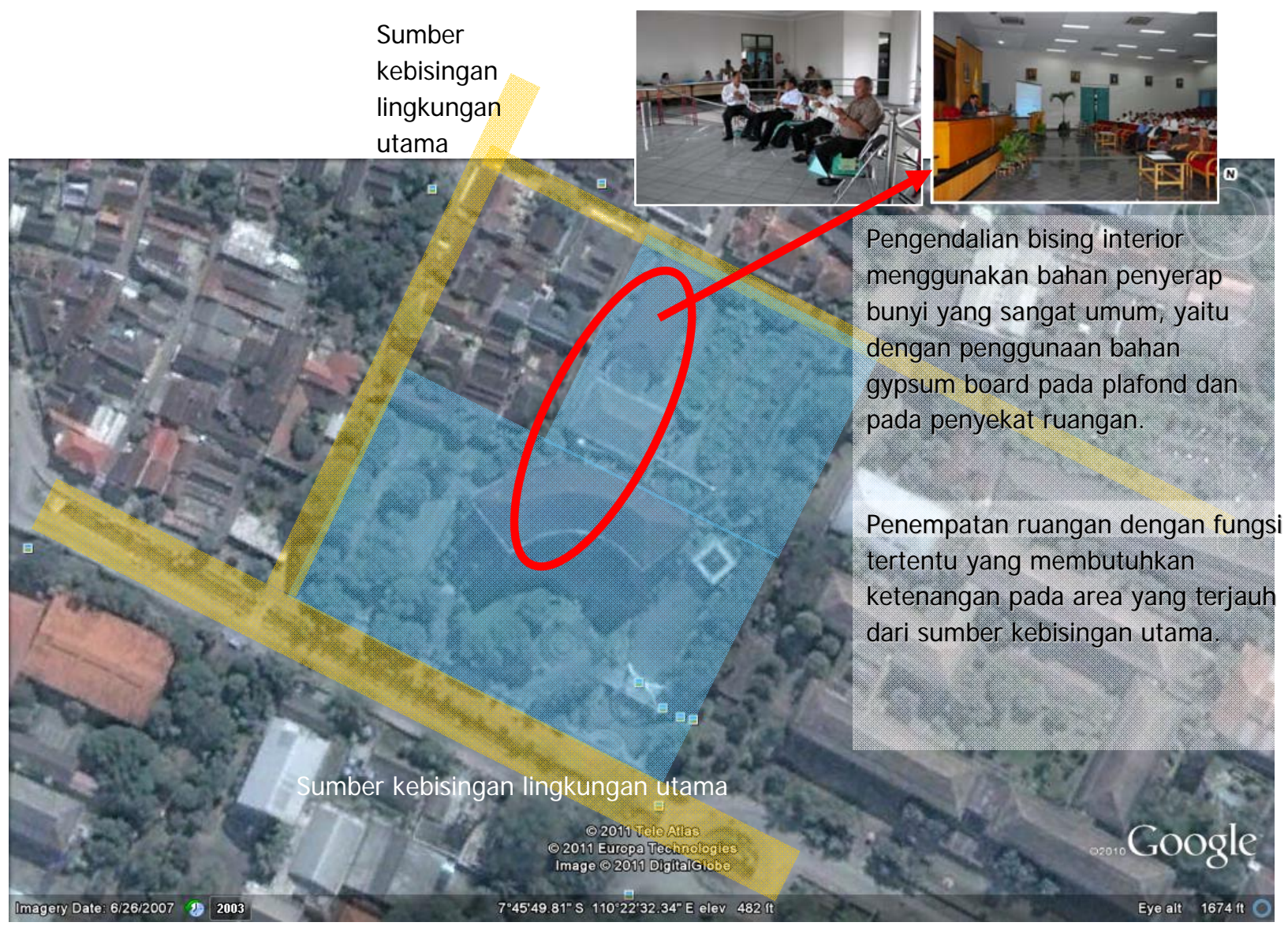

Gambar 5. Pengendalian Kebisingan Dilakukan Terhadap Kebisingan Interior Gedung Pasca Sarjana UGM Yogyakarta.

Pengendalian bising lingkungan yang dilakukan di gedung pascasarjana UGM ini meliputi pengendalian bising interior maupun ekterior bangunannya. Pengendalian bising interior lingkungan masing-masing di ruangan kantor pengelola/ administrasi, ruang lobby, ruang sidang/ruang kelas. 
Pengendalian bising interior yang dilakukan di gedung ini tidak menggunakan metode khusus, hanya menggunakan bahan penyerap bunyi yang sangat umum, yaitu dengan penggunaan bahan gypsum board pada plafond dan pada penyekat ruangan. Upaya ini dapat mengurangi tingkat bising yang terjadi di dalam gedung ini. Pada gedung ini pengendalian bising lebih ditekankan pada pengendalian bising eksterior. Diharapkan dengan bising eksterior terkendalikan maka interior gedung hanya memerlukan sedikit upaya pengendalian bising.

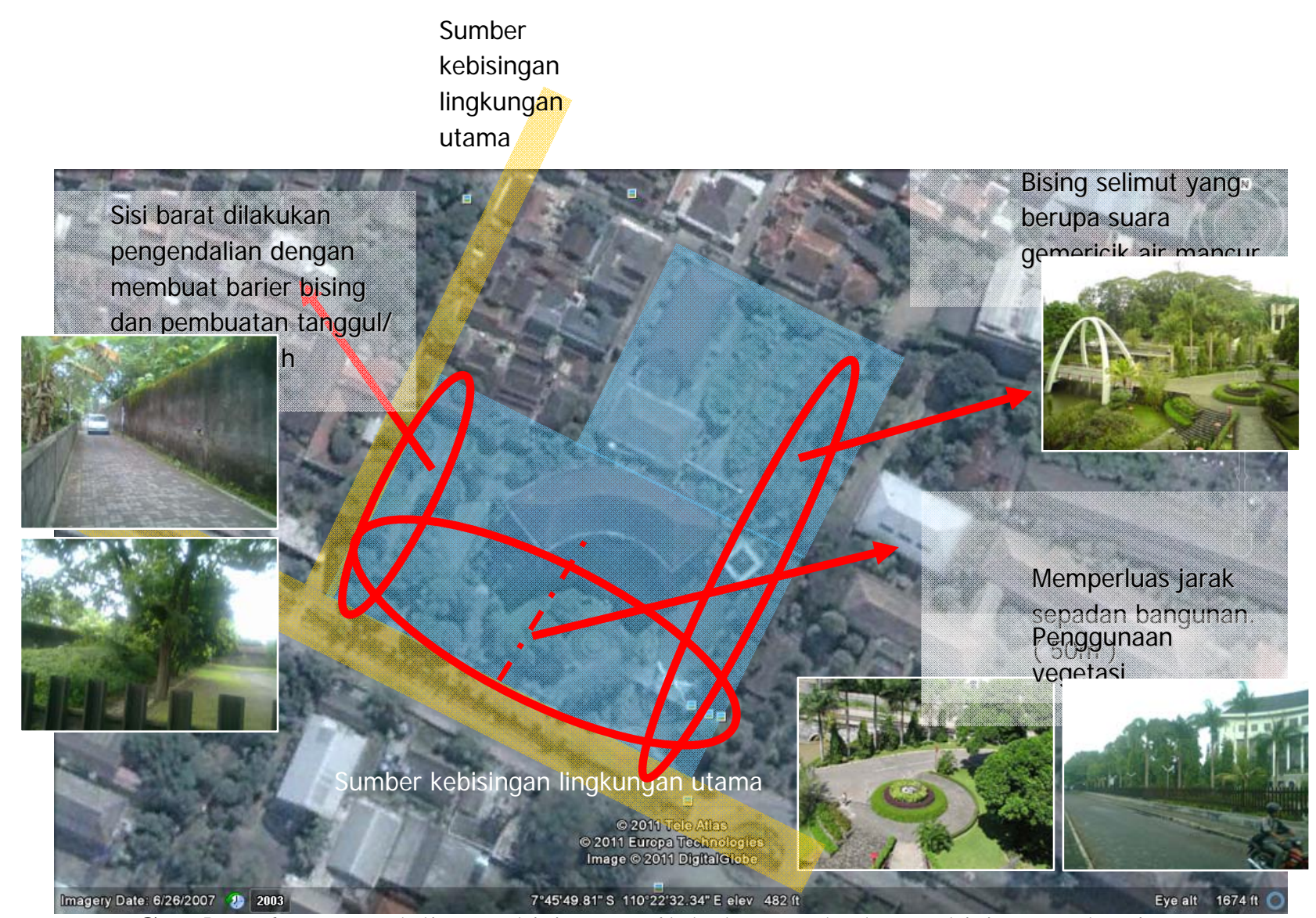

Gambar 6. Pengendalian Kebisingan Dilakukan Terhadap Kebisingan Ekterior Gedung Pasca Sarjana UGM Yogyakarta.

Pengendalian bising eksterior lingkungan dilakukan dengan beberapa langkah. Gedung pascasarjana UGM berlokasi di kawasan yang sedang berkembang pesat. Arah orientasi bangunan ini menghadap selatan. Site gedung ini memiliki batas utara jalan Kinanthi, batas barat berbatasan dengan jalan lingkungan yang menghubungkan kampung Pogung dan kawasan Kampus UGM, batas selatannya adalah Jalan Selokan Mataram.

Kebisingan yang terjadi di kawasan ini terutama adalah kebisingan yang disebabkan oleh arus lalu lintas kendaraan yang melintasi jalan di sisi utara, sisi barat dan sisi selatan bangunan. Pada sisi barat dilakukan pengendalian dengan membuat barier bising yang cukup tinggi dengan tembok setinggi kurang lebih tiga meter, ditambah dengan pembuatan tanggul atau gundukan tanah sebagai 
peredam suara kendaraan bermotor yang melintas di sebelah barat gedung ini. Usaha yang dilakukan ini cukup efektif meredam bising yang terjadi. Dengan dibangunnya tanggul ini bising lalu lintas seolah tidak ada.

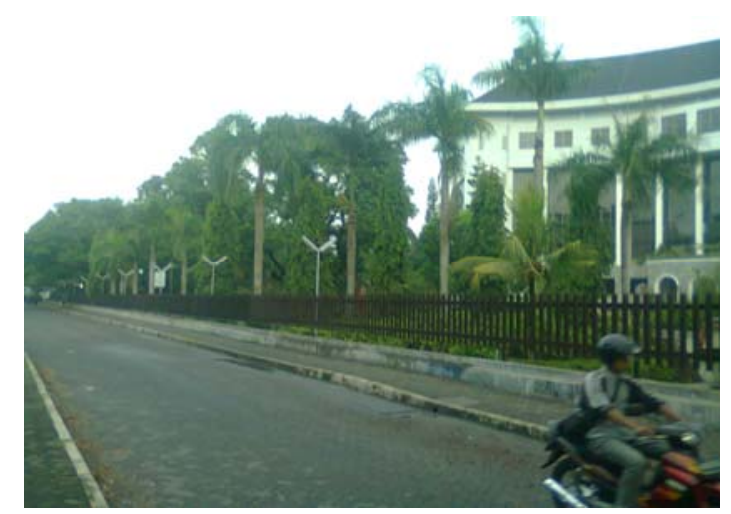

Gambar 7. Pengurangan kebisingan melalui media transmisi yang dilakukan pada bangunan Pasca Sarjana UGM yogyakarta dengan memperluas sempadan bangunan dan penanaman vegetasi pada sepanjang sumber kebisingan.

Pada sisi selatan yang merupakan jalan utama memasuki halaman gedung ini, pengendalian kebisingan dilakukan terutama dengan penggunaan vegetasi dan dengan memperluas jarak sepadan bangunan. Hal ini juga dilakukan pada pengendalian kebisingan di sisi utara. Perluasan sempadan bangunan ini dimanfaatkan untuk perencanaan lansekap yang cukup baik.

Pengendalian bising eksterior pada bangunan ini juga dengan menggunakan cara menciptakan bising selimut yang berupa suara gemericik air mancur di kolam yang dirancang cukup baik. Bunyi bising selimut dari gemericik air ini cukup efektif dalam hal pengendalian bising eksterior lingkungan gedung ini. Air mancur secara arsitektural menjadi point of view kawasan sekaligus juga bermanfaat sebagai upaya pengendalian bising lingkungan.

Semua upaya yang dilakukan di gedung pascasarjana UGM dalam pengendalian bising lingkungan cukup efektif mengurangi tingkat bising yang terjadi di kawasan ini. Kawasan ini menjadi kawasan yang kondusif sebagai sebuah gedung fasilitas pendidikan. Walaupun gedung ini tidak digunakan sebagai tempat proses perkuliahan mahasiswa sehari-hari, tetapi banyak digunakan sebagai tempat kegiatan yang mendukung proses belajar mengajar seperti kegiatan administrasi, sidang disertasi doktoral, seminar-seminar dan kegiatan pendidikan lainnya.

\section{Kesimpulan dan Rekomendasi}

Dari pembahasan diatas dapat diperoleh beberapa kesimpulan:

a. Pengendalian kebisingan di Gedung Pascasarjana UGM Yogyakarta menunjukan indikasi keberhasilan menciptakan lingkungan yang nyaman dan kondusif untuk kegiatan pendidikan. 
b. Pengendalian bising lingkungan yang dilakukan di gedung pascasarjana UGM dapat dijadikan referensi dalam merancang sebuah fasilitas pendidikan yang cukup kondusif dilihat dari segi rendahnya tingkat bising lingkungan yang tercipta.

Dari pembahasan dan kesimpulan diatas dapat diperoleh beberapa rekomendasi yang dapat digunakan untuk perancangan pengendalian kebisingan pada fasilitas pendidikan yaitu:

a. Pemilihan site atau lokasi fasilitas pendidikan dioptimalkan pada daerah dengan kepadatan penduduk rendah dan diusahakan tidak pada pusat ekonomi,hal ini karena mengurangi kepadatan lalulintas yang ada dikawasan tersebut yang akan menambah intensitas kebisingan lingkungan.

b. Pengendalian kebisingan interior, efektif dilakukan dengan perancangan organisasi ruang yang mempertimbangkan fungsi dan tingkat kebisingan yang diijinkan untuk fungsi bersangkutan. ruang yang membutuhkan ketenangan ditempatkan paling jauh dengan sumber kebisingan dan demikian juga sebaliknya.

c. Pengendalian eksterior dapat dilakukan dengan menggunakan penghalang dan atau barier bising, memperluas sempadan bangunan, meletakan bangunan yang membutuhkan ketenangan pada posisi terjauh dari sumber kebisingan lingkungan yang ada. Selain itu dapat menggunakan parfum akustik yang berupa gemericik air untuk menyamarkan kebisingan lingkungan yang terjadi.

Di samping itu juga lingkungan yang tidak bising mengurangi tingkat agresifitas dan atau kriminalitas yang mungkin terjadi di lingkungan kampus selain mengurangi tingkat stress pelaku pendidikan.

\section{Daftar Pustaka}

Arifin, E. Zaenal. (2006). Dasar-Dasar Penulisan Karya Ilmiah, PT. Gramedia Widia Sarana Indonesia, Jakarta.

Catanese, Snyder. (1991). Pengantar Arsitektur, Penerbit Erlangga, Jakarta.

Leslie L. Doelle, Prasetio Lea. (1986). Akustik Lingkungan, Penerbit Erlangga, Jakarta.

Paul A. Bell, Thomas C. Greene, Jefrey D. Fisher, dan A. Baum. (2001). Environmental Psychology, Harcourt College Publisher, New York.

Preiser, Rabinowitz, White. (1988). Post Occupancy Evaluation, Van Nostrand Reinhold Company. Sarwono, SW. (1992). Psikologi Lingkungan, PT. Gramedia Widia Sarana Indonesia, Jakarta. 